\title{
Collectivism versus individualism in Dutch employment relations
}

\author{
Jan de Leede, Jan Kees Looise and Maarten van Riemsdijk \\ University of Twente, Netherlands \\ Human Resource Management Journal, Vol 14 no 1, 2004, pages 25-39
}

From a very centralistic and collectivistic tradition after World War Two, Dutch employment relations now show a trend towards radical decentralisation and individualisation. What might be the consequences of this trend for labour relations? Do developments still fit within a movement towards 'organised decentralisation' or will the existing system of labour relations be hollowed out and destroyed? And what will be the consequences for ER management at company level? We present empirical data on how companies deal with their decentralised and individualised employment relations. It appears that, in the main areas such as labour contracts, working time arrangements, reward systems and development plans, decentralisation and individualisation are taking place. It has also become clear that management as well as workers support this and that a new form of negotiation between them is developing at workplace level, resulting in what we call 'third contracts' that are additional to the initial labour contract and the collective agreement. Our results also highlight the pragmatic way in which companies deal with these decentralised and individualised employment relations, which, nevertheless, remain linked to the national and collective levels of bargaining. Within the multilevel system of Dutch employment relations a new balance between collectivism and individualism is emerging.

Contact: Jan Kees Looise, Department of Human Resource Management, Faculty of Business, Public Administration and Technology, University of Twente, Box 217, 7500 AE Enschede, Netherlands. Email: j.c.looise@utwente.nl

$\mathrm{n}$ most Western countries we are witnessing a transition from traditional, centralised and collective industrial relations to a more decentralised and individualised approach to employment relations. The trend around the globe is similar, although there are large differences in the nature as well as the pace of the transition process. With respect to the nature of the transition, Traxler (1995) made a useful distinction between organised and disorganised decentralisation of industrial relations. Organised decentralisation means that:
...the focal collective agreement concluded at the predominant level delegates certain bargaining issues to regulation at lower level within a binding framework, set by the focal collective agreement. In the context of organised decentralisation, agenda setting and control over the lower level thus remain with the focal collective agreement. As regards comparative classification, this implies that organised decentralisation does not cause a change in the most important bargaining level.
Traxler, 1995: 5

As the Netherlands can, so far, be seen be seen as an example of the 'organised' group, it is interesting to evaluate how the process of decentralisation takes place in practice and - more importantly - what the effects are for the existing system. Given 
the high pace of the developments within the Netherlands during recent years, can organised decentralisation be sustained or will it change into a disorganised variant?

In this article, we present such an evaluation based on a research project carried out on behalf of the Foundation for Management Studies in the Netherlands during the second half of 2000 and the first half of 2001 (Huiskamp et al, 2002). During this period, 12 in-depth case studies were undertaken within nine large Dutch companies spread across different sectors, all with reputations as innovators in this field of management relations. The goal of the study was to explore the impact of the trends in decentralisation and individualisation on Dutch employment relations.

Four questions guided this study:

1 In what areas and in which ways do companies decentralise and individualise their employment relations?

2 How effective are these new employment relationships, both from an employer's and an employee's perspective?

3 How is the process of decentralisation and individualisation managed and controlled by employers?

4 What are the long-term implications for the wider Dutch model of employment relations?

Before presenting our empirical data, we begin with a short overview of the developments and drivers in the decentralisation and individualisation of Dutch employment relations. We conclude with a reflection on the possible consequences of our findings for future developments.

\section{DECENTRALISATION AND INDIVIDUALISATION}

Following Nagelkerke and Wilthagen (2002), Dutch employment relations during the period 1945-1985 can be characterised by four main features: a relatively centralistic way of decision-making, partly due to a large government influence; collectivistic and uniform regulations; institutional integration of several levels; and good adaptability of the main actors in institutional change.

The centralistic approach to decision-making and the influential role of the government are especially reflected in the way that wages were fully set by the government during the first 20 years after World War Two, and also strongly regulated during the next 20 years. According to Windmuller (1969), 'no other system of administered wage determination has done so well for an equally long period of time'. Collectivistic and uniform regulations were the other results of this approach. Although from the 1960s onwards employers' and employees' organisations played a growing role in Dutch wage determination, their activities were co-ordinated and integrated within the existing institutional bodies such as the Foundation of Labour (a bipartite institution in which the central employers and employee organisations co-operate on all issues concerning labour and wage conditions) and the Social Economic Council (a tripartite institution that advises the government on all laws and other government measures in the field of labour in a broad sense). Both institutions are still active and reflect the Dutch polder mentality: the inclination to co-operate and adapt to new circumstances when things become difficult. (A polder consists of land that has been reclaimed from the sea and the image represents our centuries'-long struggle to keep our feet dry.)

These last two characteristics, co-operation and adaptation, also became apparent when Dutch economic circumstances fell back dramatically in the 1980s. The result was the so-called Wassenaar Agreement of November 1982, in which the government and the central employers' and employees' organisations agreed on: 
a reduction in wages in exchange for a reduction in working time, such that the combination would lead to an increase in employment;

the acknowledgement of each other's positions and responsibilities, leaving the responsibility for negotiation over labour conditions to employers (organisations) and unions, and the responsibility for legal regulations and national budgets to government; and

a gradual decentralisation of collective bargaining from national to industry and company levels.

In combination with a government policy aimed at welfare reform, fiscal conservatism and the maintenance of overall social security, the Dutch economy was within 10 years able to halve its unemployment rate and to transform its image from that of a 'Dutch disease' into one of a 'Dutch miracle' (Visser and Hemerijck, 1997).

The decisive event in this development has been the consequent and subsequent translation of the central agreement into numerous sub-agreements and other deals at a decentralised level. It has functioned - and so far maintained its position - as a framework and a point of reference for decentralised negotiations, which is why the central agreement is sometimes referred to as 'the mother of all agreements'. This has resulted in a multilevel system of negotiations and adaptation, stretching out from the national level and central institutions such as the Foundation of Labour and the Social Economic Council, through sector or industry negotiations, down to the company and even lower levels (ie departments and individuals). Through this mechanism, the Dutch economy has been able to adapt quickly to the new economic, technological and socio-cultural developments of the second half of the 1980s and the 1990s, such as growing international competition, the dramatic increase in the flexibility of production and labour (Bolwijn and Kumpe, 1990; Looise et al, 1998), the demographic changes (Social Economic Council, 2001), and the need for an more individualised approach (Felling et al, 2001).

Within the polder context, the collective agreement should be seen as the cornerstone of Dutch employment relations (Van den Toren, 1998). In the Netherlands there are about 900 collective agreements of which about 200 are industry-wide and the rest company agreements. Eighty-six per cent of the workforce are covered by collective agreements, about 10 per cent by a company contract and the rest by industry contracts (including civil servant contracts). Apart from the collective agreements, there are about 200 other treaties covering specific aspects of labour conditions. Since the Wassenaar Agreement, considerable 'collective agreement innovation' has taken place. In the first place, the percentage of employees covered by such agreements has grown, especially as a result of an increase in the number of company agreements (Van den Toren, 1998). Secondly, agreements have been 'broadened' so that they now cover more topics. This especially concerns labour market issues such as employment options for weaker groups in the labour market, employability and mobility, education and training, but also 'societal issues' such as environmental matters (Huiskamp and Van Riemsdijk, 2001). The third - and in this context most important - development has been the restructuring of the collective agreement itself. In most cases the detailed prescriptions in the form of standard regulations have now been replaced by framing regulations, in which only guidelines for each subject are laid down and space is provided to fill in particulars at decentralised levels. In this context, the term 'empowerment' is used, reflecting the opening up of clauses for groups of employees or individuals to negotiate their own specific regulations within the broader context of the framework regulations.

An interesting example of this last development can be found within the Dutch part of the Anglo-Dutch multinational Unilever (Suijkens and Miltenburg, 2000). During 
1998 and 1999 a new approach towards the collective agreement(s) was 'invented' with the full co-operation of both management and unions. As a result, the existing large number of collective agreements and other arrangements for special groups of employees (such as white-collar workers) were replaced by one 'decentralised' collective agreement for almost all employees in the Netherlands. 'Decentralised' here means that the collective agreement is built up according to a 'cascade model'. Five levels of negotiation are distinguished: central (Unilever Netherlands), business unit, production or sales unit, team and individual. At all five levels, agreements can be reached on a range of subjects, albeit within limits set by the level above. At the central level, general guidelines are negotiated between the management of Unilever Netherlands and the unions on wage changes, pensions, sickness arrangements etc. These guidelines are 'translated' to meet the specific needs of the business units by the management of those units, again with the unions involved but also including a delegation of the works councils. The next step is the establishment of more detailed arrangements (regarding working hours, shift work, training and development plans etc) at the level of the production or sales units by management and works council. This will again be followed by more detailed arrangements (again on working times, negotiations over free days, the use of à la carte reward systems etc). Similar developments can be found in other large international companies such as Akzo-Nobel, Philips and Origin and in a number of sectors with industry contracts such as the graphics-media and financial sectors (Van der Meer and Smit, 2000; Nagelkerke and Wilthagen, 2002).

An important and practical question that arises in connection with this development is how far the organised decentralisation of employment relations can go before the system will become hollowed out and destroyed. The Unilever example reflects a strong, organised setting; the amount of empowerment at the lower levels is still determined by the space offered by the higher levels. However, with the opening up of elements of negotiations to decentralised parties (managers, works councils and individuals), there is a risk that sooner or later they will take the lead in this process.

From the 1990s onwards, decentralisation and individualisation seem to have been the dominant trends in the restructuring of modern employment relations. This change in direction is not only evident in the aforementioned trends, but a more fundamental change is that companies and individuals now seem to take the lead in shaping the new framework whereas, formerly, the relationship was dominated by the government and all sorts of centralised institutions. In the international literature this change is reflected in the fact that the concept of employment relations has replaced that of industrial relations ( $c f$ Blyton and Turnbull, 1994; Marchington and Parker, 1990; Locke et al, 1995). Whereas industrial relations are linked to the bargaining between employers' and employees' organisations and government at a central (national or industry) level, and with labour laws and collective agreements, the concept of employment relations reflects decentralised bargaining between individual employers and employees on all levels but especially at company or even department or group level. Can decentralised and individualised employment relations coexist alongside collective industrial relations or will they replace them in the long run? If so, what will be the consequences for company level employment relations management, and for the co-ordination of this management at industry and national levels?

Before answering these questions, we first present our data on decentralisation and individualisation at the company level. 


\section{COMPANY LEVEL}

In this section we present our findings regarding the first three research questions: the areas and ways of decentralisation and individualisation, the effects for both management and employees, and the way these processes are managed and controlled. As suggested in the introduction, we used a cross-sectional, multiple case study approach. In seven companies all the management practices were studied, and two further companies were included as 'mini-cases' in which we focused on one practice.

Cases came from the chemical, financial services and insurance, retail, ICT (information and communication technology) and healthcare sectors. All the companies were selected by reputation (as being forerunners in decentralisation and individualisation) or for having an existing policy on at least one of the areas under investigation. Subsequently, in each company the study focused on those aspects of employment relations that were the most decentralised and individualised. Ideally, the company would also have carried out internal evaluations.

In each company interviews were held with HR managers, works council members and line managers. In addition, at each location we held at least one group interview with a diverse mix of employees. A semi-structured interview protocol was adopted and, based on the information collected, a 'decentralisation and individualisation profile' was developed for each company, indicating the state of renewal of employment relations. The analysis of the individual and the group interviews was completed by the research team as a whole. One of the researchers would write the company case report and the other two would then read it and contribute comments. After this, the findings were reported back to the contact people at the companies for confirmation. This procedure led, in some cases, to minor modifications to the report.

The data collection took place in the second half of 2000 and the first half of 2001. At that time the economic climate was seen as being at the top of a boom across all sectors and, subsequently, the labour market in the Netherlands has become very tight.

\section{Areas and ways of individualisation}

In our study we found most decentralisation and individualisation in four main areas of the employment relationship:

Type of labour contracts In the Netherlands labour contracts are generally regulated by law. Until 1998 the law was rather rigid. A new law, called 'Flexibility and Security', was brought in, and companies now have far more freedom in using different forms of flexible contracts. Most collective agreements contain rules on the use (in terms of percentages) of flexible contracts. Here, we focus on the extent of contract variety. We distinguish between fixed contracts, flexible contracts (temporary work and agency work), part-time contracts (less than 32 hours a week) and function contracts (agreements on output and wages are laid down in the contract, but not time).

Working time and leave These topics are partly regulated by law and partly by collective agreement. In 1996 a new law came into effect which offered more freedom to companies to negotiate their own working times - within legal constraints - with unions or works councils. These arrangements are laid down in collective agreements (with unions) and/or company arrangements (with works councils). Our study includes the practices on variable working times (such as annualised hours and individual working hours) and flexible leave schemes (such as sabbaticals).

Reward systems and performance Reward - in connection with function or competencies weighting - is, in the Netherlands, usually covered by collective agreements. Within or 
alongside this framework, other reward arrangements, such as performance rewards or rewarding special groups, have to be negotiated with the works council. In addition, systems of performance appraisal have to be approved by the works council. In our study this area covered instruments such as performance pay and performance appraisal that made individual reward systems possible. Cafeteria plans (à la carte reward systems) and flexible pension schemes were also looked at.

Job design, training and development Most collective agreements in the Netherlands cover topics in this area, although in most instances these regulations are rather general with only vague intentions. Most large companies have their own regulations - negotiated with the works council - which are more concrete and detailed. In our study the emphasis was on personal development plans, personal education plans, personal employability plans etc. The case study on job design concerns teleworking.

We will now take a closer look at each of the four areas of employment relations.

Contract variety Three cases focused on the issue of contract variety. In the hospital case, 85 per cent of employees had a permanent, full-time contract. The other 15 per cent had temporary and/or part-time contracts. Employees with contracts for less than 0.6 fulltime equivalent belonged to an in-house agency. The main objective was to address the demand for part-time contracts by employees. The hospital wanted to retain qualified personnel and to attract new staff by providing part-time opportunities.

Within the technical consultancy case, contract variety was limited to a specific business unit. This particular business unit had to cope with marked changes in work demand due to a four-year cycle in carrying out legal tasks in estate assessments. During the peak it hired in extra personnel from other business units and from outside using management agreements (a form of freelance contract). Many of these independent consultants were former employees. In this way, the company was able to cope with the peaks. However, some complaints were heard from their own personnel who felt that their former colleagues were hired at high rates for special and interesting jobs while they were left with the more routine tasks.

In the telecommunications company, so-called 'output contracts' were introduced a few years ago for senior employees. Employees with such contracts were assessed only on their output. Within the contract there were no directions as to time laid down; only the output and the reward (a maximum 12 per cent bonus on top of the normal annual salary) was specified.

Working time Here, we studied two cases. In the healthcare insurance case, the company had introduced flexible working times in the mid-1990s. Each work unit (department) was responsible for its own yearly timetable which was updated monthly. Employees had an annual number of working hours in their contract (1,734 for full-timers, pro rata for part-timers), and week by week the number of hours worked could change to balance the needs of the work unit and of the employee. The process of decisionmaking within the groups on the time to be worked had improved after some initial tensions and imbalances between private and business needs. Another difficulty that remained was in the definition of overtime. This was defined as working hours on top of the annual number of contract hours that were compensated for by extra money or free time, but many employees claimed that their overtime during busy periods was not fully compensated for during quiet periods.

In the retail case, a similar system of annualised hours was in place. The company called it a 'working hours current account', which was supported by an automated presence registration system. The actual number of hours worked was compared with the contractual number on an annual basis. Departmental managers, together with 
their employees, planned the timetable two weeks in advance. Within an experiment, the employees had the opportunity to alter their annual number of hours every year, and to use an 'àla carte' system to buy or sell extra hours.

Reward systems and performance Four case studies in our study covered this topic.

The retail company referred to above also introduced a performance pay system in a specific area of its shops. Sales employees would get a lower base salary but could earn more money on the basis of their individual turnover (worth up to 10 per cent of salary) and departmental turnover (also worth 10 per cent). In combination with other changes, this variable reward system led to a profitable department and satisfied employees. Nevertheless, many employees also wanted to work with the 'working hours current account' system described above. However, due to these latter changes, they no longer belonged to this system although they worked in the same place.

The insurance company ceased its automatic incremental step salary system. Every step in the salary scale now had to be earned by positive assessments of the employee's competence.

Both the insurance and the hospital case study organisations were involved with à la carte reward systems. The insurance company employees could choose to work between 34 and 38 hours a week, with further possible exchanges between money and time; most of them ( 80 per cent) chose to work the times they were previously used to. In the hospital the àla carte system was even more elaborate, involving smaller issues such as PC and bicycle schemes and parking cards, and issues with more impact such as pensions and additional days' leave. Both organisations were keen to keep control over the choices made by the employees and, therefore, the consent of the manager was needed for choices that had an impact on working times.

Jobs and training and development We studied two personal development plans and one teleworking situation.

The company in the chemical case study had introduced a personal development system in the mid-1990s. Each employee discussed with their manager, at least twice a year, seven performance indicators (one was common to all: 'contribution to the team'; the other six were variable). Arrangements could then be made for the next period, regarding performance expectations, rewards and career development.

A similar personal development system was in place in the software company. Managers were supported by a classification of competences (30 in total) and were trained to differentiate between employees. Arrangements for the careers of the employees, including 'standard' career paths, were more formalised than in the previous system.

The hardware/software company was in the process of introducing teleworking to more and more parts of the company. Teleworking was linked to the flexible office concept; each department had a budget for office space (short-, medium- and long-stay working places) based on the number and nature of teleworking employees (incidental, regular and structural). Combined with teleworking, the company was putting more emphasis on management by results.

Company profiles Table 1 (overleaf) presents the adoption of the various practices of decentralisation and individualisation by our case study companies. All were active in most areas, seeking to decentralise and individualise their employment relations.

The main exceptions were in the first two areas, 'Contract types' and 'Working time and leave', where not every company was active. We found that the use of flexible contracts had recently decreased, probably due to the tight labour market at the time of 
TABLE 1 Overview of individualisation practices in the case companies

\begin{tabular}{|c|c|c|c|c|c|c|c|c|c|}
\hline & \multicolumn{9}{|c|}{ CASE STUDY ORGANISATIONS } \\
\hline & 1 & 2 & 3 & 4 & 5 & 6 & 7 & 8 & 9 \\
\hline & 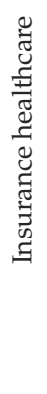 & 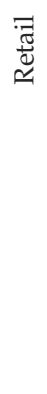 & 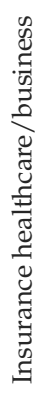 & 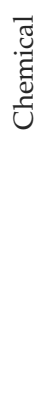 & 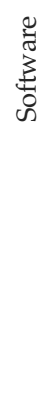 & $\begin{array}{l}\bar{\pi} \\
\frac{\pi}{2} \\
\text { के } \\
\text { 足 }\end{array}$ & 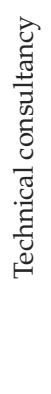 & 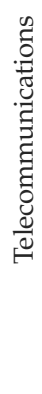 & 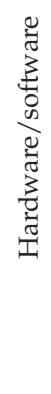 \\
\hline \multicolumn{10}{|l|}{ Contract types } \\
\hline Flexible & & $x$ & & & & $x$ & $X$ & - & - \\
\hline Part-time & $x$ & $x$ & $x$ & & & $x$ & & - & - \\
\hline Function & & & & & & & & $x$ & - \\
\hline \multicolumn{10}{|l|}{ Working time and leave } \\
\hline Variable working times & $X$ & $X$ & $\mathrm{x}$ & & & & & - & - \\
\hline Leave & & $x$ & $x$ & $\mathrm{x}$ & & $\mathrm{x}$ & $x$ & - & - \\
\hline \multicolumn{10}{|l|}{ Reward systems and performance } \\
\hline Performance reward & $x$ & $X$ & $X$ & $x$ & $x$ & & $x$ & - & - \\
\hline A la carte & & $\mathrm{x}$ & $X$ & $x$ & $x$ & $X$ & $\mathrm{x}$ & - & - \\
\hline Flexible pension & $\mathrm{x}$ & $x$ & $x$ & $x$ & $x$ & $x$ & $x$ & - & - \\
\hline \multicolumn{10}{|l|}{ Job design/training and development } \\
\hline Personal development plan & $x$ & $\mathrm{x}$ & $x$ & $X$ & $X$ & $\mathrm{x}$ & $\mathrm{x}$ & - & - \\
\hline Career & $x$ & $\mathrm{x}$ & $x$ & $x$ & $x$ & $x$ & $\mathrm{x}$ & - & - \\
\hline Job design (including teleworking) & & & & & $x$ & $x$ & & - & $X$ \\
\hline \multicolumn{10}{|c|}{$\begin{array}{l}\text { Notes } \\
\mathrm{x}=\text { individualised HR practice present within the company. } \\
\mathrm{X}=\text { individualised HR practice studied extensively within the company. } \\
\text { Cases } 8 \text { and } 9 \text { are mini-cases in which only their practices in terms of function contract (telecom) and } \\
\text { teleworking (hard/software) are included in the study. }\end{array}$} \\
\hline
\end{tabular}

our research. Now, given the economically less favourable times, there may be a renewed interest in such flexible labour strategies.

The similarities between the companies in 'Reward systems and performance' and 'Job design/training and development' are remarkable. As we also know from other studies, many companies are already working with à la carte reward systems and personal development plans or are intending to introduce them (Hay/Kluwer, 2001). We can conclude that imitation, rather than innovation, is leading these companies to make changes. In tight labour markets, companies do not want to lag behind others in attracting and retaining employees.

\section{Effectiveness and employee responses}

The effectiveness as assessed by employers and employees (related to research question 2) has been broadly operationalised. Managers were asked to evaluate the individualised 
HR practices in terms of their satisfaction with them regarding the flexibility to cope with fluctuations in the demand for labour and the extent to which they contributed to attracting and retaining employees. Employees were asked to evaluate the extent to which the practices served their individual strategies and the fairness of the HR practices.

Management responses Managers mainly reported positive effects of the implemented individualised employment terms. They were especially satisfied with the instruments concerning 'Contract types' and 'Working times' and saw them as leading toward a better fit between the availability of labour capacity and the actual production demand. This was an important trigger for introducing these instruments in the first place, with flexibility of labour being the main goal. The companies were extending this policy as much as they could, even trying to match individual working times with the needs of the company. However, not all the goals were achieved since these practices did not succeed in attracting new or retaining existing personnel.

In general, the management representatives also reported favourably on 'Reward systems and performance' and 'Job design/training and development' instruments. These practices aimed to support a more performance- and business-like orientation in the employees. By linking reward systems to employee performance, and individual development to business competences, these goals were largely met. Again, managers were not satisfied with the organisational commitment that the instruments were supposed to enhance - the instruments were of little help in retaining people. A possible explanation may be that the companies were operating in a tight labour market during the research period.

Employee responses Employees were also largely positive about the instruments. They felt that the instruments were supporting them in realising their individual strategies. They stated that most provided employees with more clarity and fairness in their personal development and careers:

In the sales department employees are more extrovert and are used to speaking up, but that is not the same for the technical employees in field service. Now our personal development plans are more formalised, we are also able to speak up and to follow training for our career steps.

\section{Employee, software company}

The new instruments enabled employees to deal with their changing attitudes to working long hours and the amount of money they needed. However, especially on the issues of contract type and working times, they expressed the view that more could be done to meet their expectations and that the work-family balance could be improved by extending the possibilities of flexible working times. From the group interviews we concluded that changes in preferences and opinions were, to a large extent, related to stages in life. Young, double-income employees had different preferences to older people or mothers with schoolchildren. The link between preferences and life stages implies a certain stability and predictability about the overall preferences of large groups of employees:

We think the 'current account' system of working hours is ideal for double-income families. When we are pregnant or the children are demanding there are possibilities to work fewer hours and you have the possibility of adjusting your timetable to your private situation.

Women employees, retail company

The employees also reported that the more the employment relationship was individualised, the more the bargain became explicit, especially in cases where 
targets and agreements were put on paper and signed by both by the manager and the employee:

You have to discuss with your manager the performance indicators. What targets is it possible to meet? You must be careful, because you have to reach the goals. It is like a negotiation process, and you have to be smart. You sit at the table, and now and then you have to concede some points. At the end you have got a sort of a contract. Employee, chemical company

In particular, the relationship between costs and benefits is made more explicit. The need for mutual adjustment among employees on many issues is also growing, as is the need for alignment of work and private lives. Negative examples came from employees on part-time or flexible contracts and from teleworkers, who complained about the increasing distance between themselves and the core of the company. We did not encounter any employees who continuously re-evaluated their situations to see if their expectations were being met. It seems that individualising employment relationships does not imply that employees will become strategic planners.

\section{Management of decentralisation and individualisation}

The HR management of our case organisations were asked how they arranged the introduction of the new employment conditions, and how this related to the roles of the unions and the works council. Other enquiries sought to determine how the new arrangements were laid down and maintained over the longer term.

Introduction of new practices The introduction of decentralised and individualised employment conditions in many of our companies occurred only after, or sometimes during, a process of harmonising the various HR practices within different business units. There was an initial need to harmonise the HR practices, especially in those enterprises that had seen a rapid growth through mergers and acquisitions. The companies tried to control the individualised employment relationships by keeping them as simple and straightforward as possible. We have already noted the harmonisation processes that precede individualisation, but only when systems are relatively simple can costs be controlled. Simplicity also enables easy maintenance. Nevertheless, to maintain àla carte reward systems and personal development plans is relatively labour-intensive. We might come to the rather paradoxical conclusion that individualisation encourages a simplification of the arrangements on offer.

In most of our cases, the roles of the unions and the works councils were secondary. They never took the initiative, although they were usually involved in the implementation stage. Their job was to monitor the process of individualisation, and to safeguard fairness and equity among employees. The managers continued to play an important role in the actual implementation and in the use of the individualised practices. On issues that only affect the individual employee, such as àla carte reward systems, a worker could choose from what was on offer without consulting the manager. However, where the choice made by an individual employee had implications for other employees or for the company as a whole, the manager was part of the procedure and had to give their consent to the individual's choices.

A 'third contract' as instrument In most of our case studies the agreements between employees and managers on working times, leave, performance pay, personal development plans and teleworking were formally laid down on paper or in digital documents. In some cases, the talks leading to the development of these documents had the characteristics of a negotiation process towards an agreement. We interpret this as the emergence of a new type of written contract between individual employees and 
managers. Alongside the individual formal labour contract, drawn up on entering the company (first contract), and the collective agreement (second contract), a 'third contract' is developing, containing explicit expectations on effort, output and rewards.

The constitution of this third contract is typically based on 'effort bargaining'. Some employees pointed explicitly in this direction, by referring to the targets that were set during the periodic evaluation of their performance (see chemical and telecom cases). In personal development plans, this evaluation leads to new targets for each period. After target-setting comes the process of negotiation to reach an agreement.

To define this as a type of contract bargaining implies that there are two relatively independent parties. Within companies there is always asymmetry in power relationships and therefore there is never a perfect power balance. Nevertheless, in gearing the employment relationship more towards the competences and preferences of the individual employee, some bargaining can indeed be witnessed. A contract also implies that it is possible for both parties to hold the other accountable and, indeed, accountability was a part of most individualised employment relations.

From our evidence we conclude that, although individualised working times and à la carte systems were encountered widely, in practice they are still quite closely related to the collective agreements that surround and support them. The individual may choose only from within a given framework. These are examples of what we earlier described as 'empowerment by opening clauses'. However, on issues such as function contracts, performance pay, personal development plans and teleworking, new agreements are being made between individual employees and managers beyond the scope of collective agreements. The implications of these findings for the wider Dutch system of employment relations are outlined in the next section.

\section{CONSEQUENCES FOR THE DUTCH SYSTEM}

In this section we try to answer our fourth research question about the consequences of decentralised and individualised employment relations for the existing Dutch system. Can the co-ordination and organisation between the levels survive or will a disorganised situation develop? Before we answer this, we reflect briefly on short- and long-term developments and on the possible impact of third contracts.

\section{Short and long term}

In evaluating empirical data with respect to developments in employment relations one has to distinguish between short-term cycles and longer-term structural changes. In particular, the role of the labour market during the research period has to be taken into account. Our research was carried out in a climate of booming economics in the Netherlands, with unemployment rates falling to below 3 per cent and real signs of scarcity in the labour market. This situation must have influenced events, and thus our findings, especially in terms of the extensive spread of individualisation initiatives and the pace at which they were introduced. It could be expected that, in a situation of economic recession and unemployment (which is widely expected in the forthcoming period), the pace of dissemination will slow. This is in line with the conclusions drawn by Tros (2000a) who made an indepth study of the development of Dutch wage negotiations over the period 1982-2000. He found, contrary to the widespread discussion on decentralisation, that over the first 15 years of his research period there was hardly any real evidence for it. In some aspects a tendency towards recentralisation could even be found. The Dutch social partners during those years (in line with the Wassenaar Agreement) had suggested handing over negotiation 
responsibilities to decentralised levels but at the same time they had kept a firm grip on the process at the central level. However, and again in a later publication (2000b), Tros does conclude that, starting in the second half of the 1990s, strong signs of a development towards the real decentralisation of negotiations could be observed.

It is still too early to conclude that a fundamental change in Dutch employment relations is imminent. Perhaps in the short term the impending economic recession will even result in a temporary standstill. It could be that companies return to a more centralised management of employment relationships, involving top-down decisions regarding budgets and targets. However, in the long term, we believe that the described trend towards decentralisation and individualisation will continue. There is no reason to believe that there will be changes in the driving forces we have identified, including the need for flexible organising, strategic utilisation of human capital, individualisation, and demographic and societal changes. Therefore, there will be no change in the need to tailor employment conditions to both organisational and employees' demands.

\section{The role of the third contract}

As seen earlier, individual arrangements nowadays cover a number of different issues, and large variations exist in their form and character. This stimulated our concept of a possible combination of these arrangements into a third contract. This contract should be seen as additional to the contract of employment and the collective agreement. Comparable with the extension of the contract of employment through a number of collective arrangements forming the collective agreement, the third contract extends the contract of employment through a regular reassessment of the mutual effort between organisation and employee. In our case studies we found clear evidence of the development of such third contracts. This is illustrated in a recent IKEA recruitment advertisement for new personnel (see Figure 1).

An important question is how these third contracts will develop. In fact we see three distinct possibilities:

1. Miscellaneous arrangements Within several of our companies, employees were negotiating certain aspects of the employment relationship to some extent. In the chemical company and, less so in the software firm, the employees did negotiate their performance targets and rewards through their personal development plans. In the hardware/software case, there was a formal contract regarding teleworking but, by introducing teleworking, the emphasis shifted to management by results. In the hospital and insurance organisations contracts were signed regarding choices in the cafeteria reward systems. Therefore, we may conclude that in these companies a miscellany of arrangements between employee and manager were written down and signed. There was no further integration of these arrangements; some were laid down on an annual basis (such as the yearly performance assessment), others were more frequent (for instance, working- time arrangements) or indeed much less frequent (such

\section{FIGURE 1 IKEA advertisement}

Time has gone when 'the boss' decides how your workday is organised. Everybody chooses the job that fits him or her. Even better: compose your job yourself. We make individual arrangements over working hours (varying from six to 36 hours, different parts of the day, evenings, weekends), career development, job content, education etc. We offer options at every level, in different areas, inside and outside the subsidiary, inside and outside the Netherlands. 
as arrangements for further education and careers). Some were supported by an HR information system and others were not.

2 Integrated set of arrangements Another option is that the various arrangements are bundled and integrated into one, annual, additional 'contract' between the organisation and the employee. The contract is formalised on paper and supported by, and stored in, an HR information system. Once a year there is an evaluation from both sides and, based on this, the contract is renegotiated for the following year. There is no direct relationship between the additional contract and the original contract of employment (the first contract). That is to say, a negative outcome of the yearly contract negotiations does not automatically lead to a termination of the work relationship by either party although, clearly, after several negative outcomes it might come to that. In our case studies we did not find any good examples of this variant, although some companies (eg chemical) were trying to integrate formal arrangements in the annual performance evaluations with reward, working time and career development.

3 A legal contract In the final variant the third contract has a formal legal status comparable with the contract of employment. In this situation the third contract becomes part of the first contract - in the form of an extension containing more explicit and detailed arrangements regarding working time, qualifications and performance during a given period - or may even replace it fully. In the latter case the situation is comparable with a series of non-permanent contracts for agreed periods (for example, the duration of a project), with repeated negotiations about the conditions. In the telecom company, given its use of output contracts, the situation approached this variant. These output contracts are annually renewed formal contracts in which the output is laid down using measurable targets, including the rewards to be earned. However, such contracts are not fully integrated, since other issues such as career development are not covered. The management agreements in the technical consultancy were also close to this variant. However, contracts went beyond traditional employment relationships since the employees have become independent entrepreneurs.

Our case studies suggest that the first variant is still the most common but that one can see a development towards the second variant, in which the third contract offers new options for HR managers to align the different HR instruments to the HR strategy, the business strategy and the individual strategies of employees, as shown in Figure 2. From this viewpoint, the third contract is a mechanism to align business, HR and individual strategies. The third contract can be expected to reflect the relative strengths of the positions of each of the actors.

However, we do not expect the third variant to become dominant despite it already existing in the form of flexible contracts. An excess number of flexible contracts leads to

FIGURE 2 The 'third contract' as a vehicle for alignment

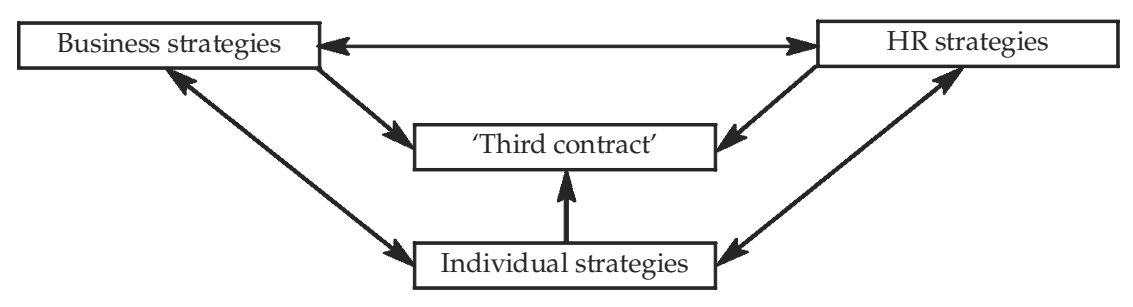


increased transaction costs for companies and can also become a threat to its continuity and quality. As long as there is a need for stable (to a certain extent) and reliable organisations there will also be a need for more permanent employment relationships.

\section{CONCLUSION: SEARCHING FOR A NEW BALANCE}

Reflecting on the findings from the case studies and their consequences for the existing system of employment relations, we think that a new balance has to develop. On the one hand we expect to see the continuation of collective agreements, given the need for co-ordination of topics such as employment, wage development and social security at societal and industrial levels. Further, the need to reduce transaction costs, for economies of scale and for predictability at company level remain drivers of collective agreements. However, at the same time we also expect continuous innovation in the collective agreement - towards an instrument for the flexible arrangement of collective issues. Compared with the past, there will be less emphasis on content, rules and control, and more on finding common understandings and shared meanings. The collective agreement will become, even more so than today, a platform for the exchange of ideas and the development of recommendations, rather than a means of hard negotiation and regulation. On the other hand, there will be more use made of specific arrangements at the organisational and departmental levels, in line with the collective agreement but agreed by management and the works council. Further, within these arrangements there will be increased room for individual specifications, developed in consultation between employee and manager. Experts from employer and employee organisations will be able to support the consultations at different levels. In so doing, they will be able to convey the ideas that were laid down in the collective agreement at the central level.

We expect the multilevel characteristics of the Dutch system of employment relations to survive. The trend toward individualised employment conditions will continue, to a certain extent as a trade-off against agreements at the central and collective levels. Nevertheless, the strengths and efficiencies of the central agreements will have to be combined with the need for more flexibility and individualisation. A third contract offers, in our opinion, fresh options in the search for a new balance between, on the one hand, the continuation of collectivism and central bargaining and, on the other, decentralisation and individualisation.

\section{Note}

1 Or 'differentiated' in the phraseology of other authors in this field. We prefer the term 'individualised' because it gives a better reflection of the fact that the new arrangements are not primarily developed for specific groups (such as white or blue collar, young and old etc) but for all employees as individuals.

\section{REFERENCES}

Blyton, P. and Turnbull, P. (1994). The Dynamics of Employee Relations, Houndmills: MacMillan Business.

Bolwijn, P.T. and Kumpe, T. (1990). 'Manufacturing in the 1990s - productivity, flexibility and innovation'. Long Range Planning, 23: 4, 44-57.

Felling, A., Peters, J. and Scheepers, P. (eds). (2001). Individualisering in Nederland aan het eind de van de Twintigste Eeuw. (Individualisation in the Netherlands at the end of the Twentieth Century), Assen: Van Gorcum. 
Hay/Kluwer (2001). Jaarboek Personeelsmanagement 2001 (Yearbook Personnel Management 2001), Deventer: Kluwer.

Huiskamp, R. and Van Riemsdijk, M. (2001). 'Competitive consensus: bargaining on employment and competitiveness in The Netherlands'. Transfer, European Review of Labour and Research, 4, 682-696.

Huiskamp, M.J., De Leede, J. and Looise, J.C. (2002). Arbeidsrelaties op Maat; Naar een Derde Contract (Tailor-made Employment Relations; Towards a Third Contract), Assen: Van Gorcum.

Locke, R., Piore, M. and Kochan, T. (1995). Employment Relations in a Changing World Economy, Massachusetts: MIT Publishing.

Looise, J.C., De Lange, F. and Van Riemsdijk, M. (1998). 'Company labour flexibility strategies in The Netherlands: an institutional perspective'. Employee Relations, 20: 5, 461-482.

Marchington, M. and Parker, P. (1990). Changing Patterns of Employee Relations, New York/London: Harvester Wheatsheaf.

Meer, M. van der and Smit, E. (eds). (2000). Innovatie of Imitatie? CAO-vernieuwing op Ondernemingsniveau. (Innovation or Imitation? Renewal of Collective Agreements at Company Level), Den Haag: Elsevier Bedrijfsinformatie BV.

Nagelkerke, A.G. and Withagen, A.C.J.M. (eds). (2002). Arbeidsverhoudingen in Ontwikkeling (Development of Labour Relations), Deventer: Kluwer.

Nagelkerke, A.G. and Wilthagen, A.C.J.M. (2002). 'Arbeidsverhoudingen aan het begin van de 21ste eeuw; op weg naar een institutioneel mozaïek' ('Labour relations at the start of the 21st century; underway to a institutional mosaic') in Arbeidsverhoudingen in Ontwikkeling (Development of Labour Relations). A.G. Nagelkerke and A.C.J.M Wilthagen (eds). Deventer: Kluwer.

Social Economic Council (2001). Levensloopbanen: Gevolgen van Veranderende Arbeidspatronen. (Life Careers: Results of Changing Labour Patterns), Den Haag: Commission of Social-Economic Experts of the Social Economic Council.

Suijkens, M. and Miltenburg, J. (2000). 'De ontwikkeling van een decentrale CAO bij Unilever' ('The development of a decentral collective agreement with Unilever') in Innovatie of Imitatie? CAO-vernieuwing op Ondernemingsniveau. (Innovation or Imitation? Renewal of Collective Agreements at Company Level). M. van der Meer and E. Smit (eds). Den Haag: Elsevier Bedrijfsinformatie BV.

Toren, J.P. van den (1998). De Collective Arbeidsovereenkomst; Sleutel Tussen Belang en Beleid (The Collective Agreement; The Key Between Interest and Policy), Den Haag: Welboom.

Traxler, F. (1995). 'Farewell to the labour market associations? Organized versus disorganized decentralization as a map for industrial relations?' In Organized industrial relations. What future? C.J. Crouch and F. Traxler (eds). Aldershot: Avebury.

Traxler, F., Blaschke, S. and Kittel, B. (2001). National Labour Relations in Internationalized Markets : A Comparative Study of Institutions, Change, and Performance, Oxford: Oxford University Press.

Tros, F. (2000a). 'Decentralisering van arbeidsverhoudingen' ('Decentralisation of labour relations'). Dissertation, University of Amsterdam.

Tros, F. (2000b). 'CAO: spelbreker en grensrechter' ('Collective agreement: spoilsport or referee'). Tijdschrift voor HRM, Winter, 57-85.

Visser, J. and Hemerijck, A. (1997). 'A Dutch Miracle'. Job Growth, Welfare Reform and Corporatism in the Netherlands, Amsterdam: Amsterdam University Press.

Windmuller, J. (1969). Labour Relations in the Netherlands, Ithaca: Cornell University Press. 